\title{
Pseudocercospora fuligena Causing Leaf Mold of Tomato in Roraima, Brazil
}

\author{
Bernardo A. Halfeld-Vieira ${ }^{1}$, Kátia L. Nechet $^{1}$ \& Rosianne N. T. Barbosa ${ }^{2}$ \\ 'Embrapa Roraima, Cx. Postal 133, CEP 69301-970, Boa Vista, RR, e-mail: halfeld@cpafrr.embrapa.br; \\ ${ }^{2}$ Universidade Federal de Roraima, Centro de Ciências Agrárias, Campus do Cauamé, \\ CEP 69310-270, Boa Vista, RR
}

(Aceito para publicação em 16/07/2006)

Autor para correspondência: Bernardo A. Halfeld-Vieira

\begin{abstract}
RESUMO
Pseudocercospora fuligena causando mancha fuliginosa do tomateiro em Roraima

Este é o primeiro relato da ocorrência de Pseudocercospora fuligena em tomateiro no estado de Roraima, causando queima foliar severa. Embora sua ocorrência seja assinalada no Brasil, a doença é considerada incomum e pouco conhecida no país.
\end{abstract}

The cercospora leaf mold on tomato is an uncommon disease in Brazil. However, its occurrence is reported by Crous \& Braun (Mycosphaerella and its anamorphs: 1. Names published in Cercospora and Passalora. 2003) and in important databases as EPPO and CABI Crop Protection Compendium. In September 2005, in Roraima, Brazil, tomato (Lycopersicon esculentum L.) plants cv. Santa Clara growing in protected cultivation conditions presented a severe foliar blight. Symptoms initially appeared as foliar spots, yellow on the adaxial leaflets surface (Figure 1A), corresponding to a dark gray fuliginous growth on the abaxial surface (Figure 1B), evolving to irregular necrotic spots. As the disease developed, leaf spots coalesced. Characteristics of the associated fungi were fascicles amphigenous, predominantly hypophyllous, effuse, stromata absent or substomatal. Conidiophores pale olivaceous to olivaceous brown, 9-16 per fascicle, 20-39 x 3.5-5.0 $\mu \mathrm{m}$, 1-2 septate, conidiogenous loci inconspicuous (Figure 1C). Conidia obclavate to cylindric-obclavate, rounded to obtuse at the apex, olivaceous to subhyaline, obconic to rounded at the base, 29-110 $\times 2.5-5.0 \mu \mathrm{m}$ and 3-10 septate, hila unthickened, not darkened (Figure 1D). To perform the Koch's postulates the fungi was isolated in Potato Dextrose Agar and cultivated in Potato Dextrose broth at $28{ }^{\circ} \mathrm{C}$ in rotary shaker. After 20 days, the culture was centrifuged, dispensing the culture media. Mycelium was resuspended in sterilized tap water and triturated. Thirty-days old plants of tomato hybrid Débora Plus were sprayed with the mycelium suspension ( $1.6 \times 10^{5}$ mycelium fragments per $\left.\mathrm{mL}\right)$, kept in humid chamber for $24 \mathrm{~h}$ and then transferred to greenhouse conditions. As control, plants were sprayed with tap water. For each treatment, 20 plants were utilized. After nine days, first symptoms were observed only in plants sprayed with the mycelium suspension (Figure 1E), evolving to an intense foliar blight. The pathogen was successfully re-isolated. These features permit the identification of Pseudocercospora fuligena (Roldan) Deighton (basionym Cercospora fuligena) as causal agent of cercospora leaf mold on tomato (Chupp, A monograph of the fungus genus Cercospora. 1954; Guo \& Hsieh, The genus Pseudocercospora in China. 1995). This is the first report of P. fuligena on tomato in Roraima state, Brazil. The symptoms of the disease are easily confused with Cladosporium leaf mold.

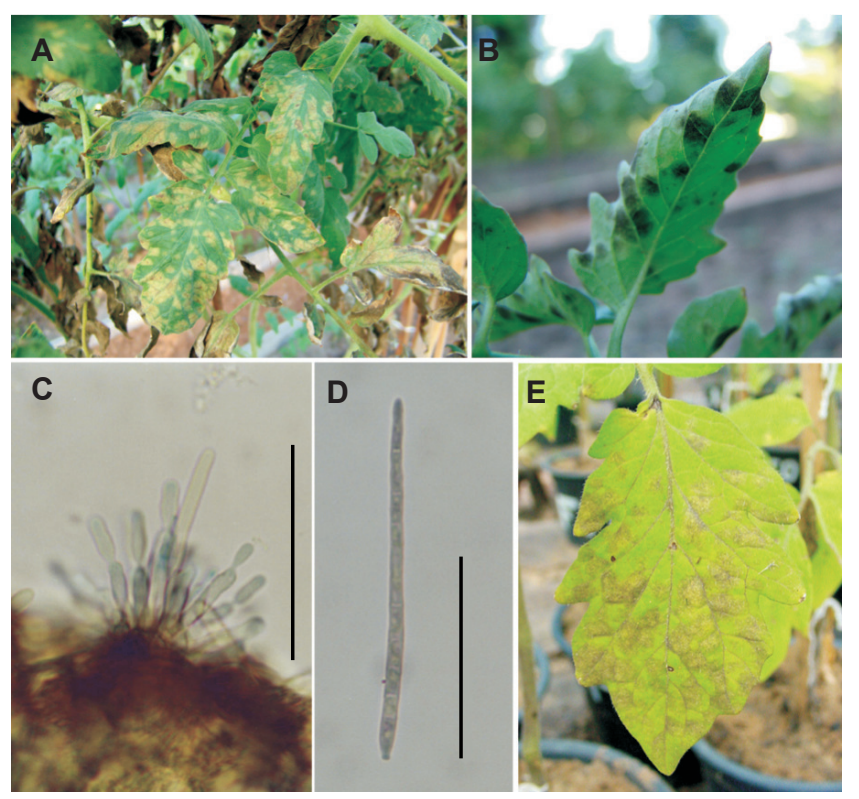

FIG. 1 - Pseudocercospora fuligena leaf spot. A. Yellow spots on the adaxial leaflets surface; B. dark gray fuliginous growth on the abaxial surface of leaflet; C. fascicle of divergent conidiophores; D. solitary cylindric-obclavate conidium (scale bar $=50 \mu \mathrm{m}$ ); E. leaf mold symptoms on inoculated plant. 